\title{
Zamke virtualnog svijeta: zaštita djece i mladih na internetu i prevencija ovisnosti
}

1 Petra Robotić

1 Studijski centar socijalnog rada, Pravni fakultet Sveučilišta u Zagrebu

\section{Sažetak}

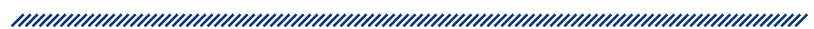

Razvoj elektroničkih medija, njihova interaktivnost i veće mogućnosti komuniciranja, uz mnoge prednosti i zanimljiv način učenja, predstavlja i vrlo velik rizik za sve, ali ponajviše djecu i mlade. Djeca i mladi danas žive znatno drugačije nego su živjeli njihovi roditelji i znaju mnogo više o elektroničkim medijima, čime roditeljska uloga postaje još složenija. Mediji danas, s naglaskom na sve većoj važnosti i prisutnosti elektroničkih medija u životima djece i mladih, postaju odgojitelji novih generacija, s obzirom na to da djeca danas provode više vremena u društvu raznih medija nego što provode $u$ školskim klupama.

Stoga su djeca i mladi u velikom riziku da ih prekomjerna upotreba ovog medija odvede u socijalnu izolaciju, što je dobra podloga za stvaranje ovisnosti.

Ovisnost o internetu još uvijek nema službenu dijagnozu u Dijagnostičkom i statističkom priručniku za duševne poremećaje, peto izdanje (u daljnjem tekstu DSM-V), kao ni u Međunarodnoj klasifikaciji bolesti i srodnih zdravstvenih problema, deseto izdanje (u daljnjem tekstu MKB-10), ali su dosadašnja istraživanja pokazala da postoji određeni broj ljudi koji pokazuju elemente po- našanja koji su zajednički ponašanju osoba ovisnih o tvarima, a posljedice se očituju u socijalnom, radnom i obiteljskom životu osobe.

Također, na internetu vrebaju mnoge opasnosti, a kako bi se djecu i mlade zaštitilo od njih, potrebna je dobra suradnja i komunikacija na relaciji dijete - roditelj škola - lokalna zajednica - društvo u cjelini, sustavno djelujući na svim razinama prevencije i zaštiti djece od mogućega štetnog djelovanja elektroničkih medija.

Ključne riječi: internet, ovisnost o internetu, elektronički mediji, zaštita djece, prevencija

Datum primitka: 30.10.2015.

Datum prihvaćanja: 19.11.2015.

Adresa za dopisivanje:

Petra Robotić, mag. socijalne politike

Tel.: 0989975845

E-pošta: petra.robotic@yahoo.com

\section{Uvod}

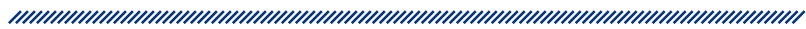

Danas je gotovo nemoguće da dijete odrasta bez računala i ostale informacijske i komunikacijske tehnologije koja čini dio naše svakodnevnice, omogućavajući djeci i mladima zabavu i povećane mogućnosti za učenje i komuniciranje, ali i način da se djeca upoznaju sa svojim pravima. 
Posebno je podložna utjecaju novog medija današnja „digitalna generacija“, djeca i mladi ljudi koji odrastaju u društvu zaslona televizora, računala i mobilnih telefo$n a^{1}$. Dok su se prijašnje generacije koristile novim tehnologijama u svojem slobodnom vremenu ili za obavljanje različitih zadataka, ova ih generacija upotrebljava kontinuirano kao način života, zapravo, „tehnologijom se ne koriste, nego je žive" ${ }^{\text {"2 }}$. Od malih nogu posjeduju odličnu informatičku pismenost i mnogo se bolje razumiju u suvremenu tehnologiju od roditelja, što dovodi do toga da djeca lako mogu manipulirati roditeljima u korištenju ovim medijem ${ }^{3}$.

S porastom dječjeg oduševljenja elektroničkim medijima povećava se zbunjenost i zabrinutost roditelja, kojima je potrebna podrška i edukacija o tome kako se nositi s tim izazovima4.

“Uloga računala kao 'isplative i nezahtjevne' dadilje pretvorila se u opasnost koja unosi nemir i zabrinutost u obitelji zbog dječje pretjerane zaokupljenosti internetom i videoigrama te društvenim mrežama na štetu drugih obveza, osobito školskih, zatim udaljavanja od prijatelja i osamljivanja, gubitka nadzora nad ponašanjem te sve težega prekidanja s tom lošom navikom i potencijalnom ovisnošću."

Djeca sve više vremena provode na internetu, društvenim mrežama i mrežnim igrama, što je rezultiralo time da se sve više govori o novom poremećaju - ovisnosti o internetu i ovisnosti o videoigrama (mrežnim igrama), kojemu su najviše podložni mladi ljudi, posebice djeca.

Također, budući da je internet javno dostupan međunarodni medij, ne postoji središnji autoritet koji bi nadzirao rad i ponašanje korisnika njegovih usluga, čime ta tehnologija u krivim rukama dobiva negativnu funkciju, nanosi zlo i vrši nasilje i zlostavljanje ${ }^{5}$.

Tu svu novu tehnologiju treba shvatiti kao korisne strojeve koji zahtijevaju instrukciju, vodstvo i superviziju odrasle osobe prije dostizanja razine u kojoj mlada osoba njima potpuno ovlada i usvoji ispravne načine korištenja i zaštite².

\section{Prednosti interneta}

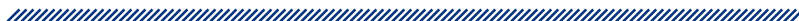

Nesumnjivo, internet je koristan alat s mnogobrojnim pozitivnim stranama kao što su:

- brza i laka dostupnost informacija

- motivacija za učenje

- izvor zabave

- omogućuje brzu i laku komunikaciju bez obzira na to gdje se nalazimo

- omogućuje razmjenu iskustva, mišljenja i informacija

- poboljšavaju se vještine pisanja djece i mladih

- potiče razvoj kreativnosti

- potiče razvoj strategija rješavanja problema i selekcije informacija ${ }^{6}$.

Omogućio nam je edukaciju, komunikaciju i zabavu, sve $u$ isto vrijeme. Omogućio nam je da upoznajemo druge ljude i kulture, da putujemo, kupujemo, kao i da pokažemo svoja znanja i talente milijunima ljudi širom svijeta. Možemo putem interneta pružiti pomoć i utjehu jedni drugima u teškim trenutcima ili podijeliti radost u trenutcima sreće, informirati se o pitanjima koja nas zanimaju i razmijeniti iskustva s drugima.

Popis mogućnosti koje nam nudi internet velik je i stalno raste, to je najmoćniji obrazovni i komunikacijski medij u povijesti svijeta ${ }^{7}$.

\section{Opasnosti interneta}

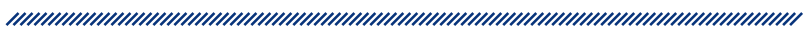

Internet uz mnoge prednosti skriva i opasnosti, posebno za djecu i mlade.

Jednu od sigurno najvećih opasnosti za djecu čine kriminalne osobe koje pokušavaju uspostaviti osobni kontakt $\mathrm{s}$ djecom i iskoristiti njihovu nezrelost i naivnost, zatim zlostavljanje putem interneta najčešće od druge djece (cyberbullying) i izlaganje seksualnim ili nasilnim sadržajima.

Tu su i opasnosti pristupa neprimjerenim sadržajima za djecu (kao što su pornografija, materijali koji potiču dis- 
kriminaciju i mržnju, krvave i nasilne scene, poticanje na uživanje droge, razne kockarske aktivnosti i dr.), ali i stranice na kojima se prodaju zakonom zabranjeni proizvodi ili potiče na zakonom zabranjene radnje, stranice koje ne štite privatnost djece i gdje djeca mogu objaviti važne ili osobne podatke te biti izložena krađi identiteta i zloupotrebi osobnih podataka, prijevarama kupovine na internetu ili riziku da otkriju važne financijske podatke, a tu je i opasnost od virusa i hakera, kao i mnoge druge opasnosti?

Zasigurno je jedan od rizika i pretjerana izoliranost djeteta zbog dugotrajnog korištenja internetom, koja može voditi u ovisnost o internetu.

\section{Prevalencija interneta u Hrvatskoj među djecom i mladima}

Prema istraživanju Hrabrog telefona i Poliklinike za zaštitu djece grada Zagreba iz 2008. godine (,Istraživanje o navikama i iskustvima djece i mladih prilikom korištenja interneta, mobitela i drugih suvremenih tehnologija") pokazalo se da gotova sva djeca uključena u istraživanje (95\%) navode da kod kuće imaju računalo, a $85 \%$ ih navodi i da ima pristup internetu kod kuće, dok se $91 \%$ djece i mladih izjašnjava kao korisnici interneta ${ }^{8}$.

Isto potvrđuje i istraživanje UNICEF-a u suradnji s Hrabrim telefonom (,Iskustva i stavovi djece, roditelja i učitelja prema elektroničkim medijima“) iz 2010. godine, prema čijim rezultatima također $95 \%$ djece ima računala, $85 \%$ ima internet, a $96 \%$ mobilni telefon ${ }^{9}$.

Prema istraživanju UNICEF-a, više se od trećine djece u dobi od 10 do 11 godina internetom koristi svakodnevno, a u dobi od 14 do 15 godina to čini većina. Omiljene su aktivnosti na internetu traženje zabavnih sadržaja (glazba, filmovi, igre), dopisivanje s prijateljima te korištenje specijaliziranim stranicama za druženje, kao što je Facebook. ${ }^{9}$

\section{Ovisnost o internetu}

\subsection{Konceptualizacija pojma ovisnosti o internetu}

Pitanje postoji li ovisnost o internetu naišlo je na dosta različitih stavova u krugovima psihijatara i psihologa te još uvijek ne postoji suglasje oko toga gdje su granice normalnog odnosno prekomjernog korištenja internetom.

Također ne postoji ni suglasje oko termina „ovisnost o internetu", oko etiologije te ovisnosti te oko najboljega metodološkog pristupa.

Primjenjuju se razni termini, od ovisnosti o internetu, patološkog korištenja internetom, problematičnog korištenja internetom do patološke upotrebe računala, ali i mnogi drugi ${ }^{10}$.

Danas bi možda najbolje bilo govoriti o kompulzivnom korištenju elektroničkim medijima, s obzirom na to da ponašanje koje je nekoć bilo povezano samo s internetom danas obuhvaća i druge interaktivne medije kao što su pametni telefoni, osobni digitalni asistenti (uređaji PDA), tablična računala, konzole za videoigre, prijenosna računala i $\mathrm{dr}^{10}$

Još uvijek ne postoji ni službena dijagnoza u Dijagnostičkom i statističkom priručniku za duševne poremećaje, peto izdanje (u daljnjem tekstu DSM-V) za ovisnost o internetu, kao ni u Međunarodnoj klasifikaciji bolesti i srodnih zdravstvenih problema, deseto izdanje (u daljnjem tekstu MKB-10), ali je u zadnjem izdanju priručnika DSM-V iz 2013. godine u trećem poglavlju pod stanjima za daljnja istraživanja uvrštena „Ovisnost o internetskim igrama"11.

Pretjerana upotreba drugih sadržaja interneta za sada se ne smatra analognom ovisnosti o internetskim igrama, a buduća će istraživanja slijedeći dane smjernice Američke psihijatrijske udruge pokazati hoće li postojati osnova da i to bude uvršteno u DSM- ${ }^{11}$.

Uvrštavanje ovisnosti o internetu u DSM-V dalo bi zasigurno veći legitimitet daljnjim kliničkim istraživanjima i omogućilo daljnje znanstveno proučavanje ovog fenomena ${ }^{10}$.

lako nema službene dijagnoze, dosadašnja su istraživanja pokazala da postoji određeni broj ljudi koji pokazuju elemente ponašanja koji su zajednički ponašanju oso- 
ba ovisnima o tvarima (drogama, alkoholu, lijekovima i dr.), a posljedice se očituju u socijalnom, radnom i obiteljskom životu osobe ${ }^{12}$. Glavni su elementi preokupiranost određenom tvari ili ponašanjem, bezuspješni pokušaji da se smanji korištenje, promjene raspoloženja kod pokušaja recidiva, korištenje u većoj količini od željenog odnosno planiranog, ugrožavanje radnog, obrazovnog ili partnerskog odnosa te laganje o korištenju ${ }^{13}$.

Stanić definira ovisnost o internetu kao „kompulzivan nagon za prekomjernim korištenjem internetskih usluga na način koji narušava fizičko i/ili psihičko zdravlje te uzrokuje teškoće u svakodnevnom obiteljskom, socijalnom i radnom životu“5.

Za razliku od dijagnoze ovisnosti o psihoaktivnim tvarima, dijagnoza ovisnosti o internetu znatno je kompleksnija, s obzirom na to da je, za razliku od alkohola i droga, internet dio našeg osobnog i profesionalnog života te je samim time znakove ovisnosti lakše maskirati i opravdati, a ovisnost o internetu može u početku biti maskirana i nekim drugim psihijatrijskim bolestima i poremećajima, kao što je depresija, anksioznost ili bipolarni poremećaj ${ }^{10}$.

\subsection{Dijagnostički kriteriji ovisnosti o internetu}

Za procjenu ovisnosti o internetu, odnosno patološkog korištenja internetom razvijeni su različiti dijagnostički instrumenti, a mnogi od njih polaze od dijagnostičkih kriterija iz priručnika DSM-IV za patološko kockanje, dok su drugi razvijeni na kognitivno-bihevioralističkom modelu i utjecaju interneta na kognitivne i socijalne funkcije osobe ${ }^{14}$.

Polazeći od dijagnostike analogne patološkom kockanju Kimberly S. Young, osnivačica Centra za internetske ovisnosti na Sveučilištu u Pittsburghu i jedna od prvih istraživača ovog fenomena, sastavila je Dijagnostički upitnik za utvrđivanje ovisnosti o internetu (IADQ -Internet Addiction Diagnostic Questionnaire) na temelju kriterija iz priručnika DSM-IV za patološko kockanje, a sastojao se od osam čestica (od originalnih deset kriterija za patološko kockanje dva kriterija nisu bila primjenjiva za ovu vrstu ovisnosti), a odgovor „da“ na pet ili više njih tijekom šest mjeseci upućivao je na ovisnost o internetu ${ }^{15,10}$.

U priručniku DSM-V patološko kockanje više nije svrstano u poglavlje „Poremećaji kontrole poriva“, već u poglavlje „Poremećaji povezani s psihoaktivnim tvarima i drugim ovisnostima“, dobivajući novi naziv „Ovisnost o kockanju“, uzimajući u obzir „dokaze da kockanje aktivira sustav za nagradu slično kao i zloupotreba droge i uzrokuje bihevioralne simptome usporedive s uzimanjem psihoaktivnih tvari“"11. Do priručnika DSM-IV izraz „ovisnost" upotrebljavao se samo za poremećaje povezane sa psihoaktivnim tvarima.

Kasnije je već spomenuta Kimberly S. Young napravila modifikaciju Dijagnostičkog upitnika za utvrđivanje ovisnosti o internetu, test pod nazivom IAT (Internet addiction test), koji u 20 pitanja putem Likertove ljestvice mjeri opseg uključenosti u internetske aktivnosti, uzimajući u obzir samo vrijeme provedeno na internetu koje nije povezano s poslom ili obrazovanjem, a ovisničko ponašanje utvrđeno testom opisuje kao blago, umjereno ili jako ${ }^{10}$. Ovaj test pruža uvid u procjenu specifičnih problematičnih područja ili problema uzrokovanih pretjeranim korištenjem internetom, kako bi se napravio plan liječenja ${ }^{10}$.

Postoje i poznati testovi kao što su PIUQ (The Problematic Internet Use Questionnaire) i CIUS (Compulsive Internet Use Scale), ali i mnogi drugi.

\subsection{Vrste ovisnosti o internetu}

Postoje različiti oblici korištenja internetom: radi traženja informacija, igranja računalnih igara na internetu, uključivanja u „pričaonice“ i razmjenu poruka e-poštom, „virtualni seks“, kockanje na internetu i trgovina putem interneta ${ }^{15}$.

Stoga ovisnost o internetu uključuje nekoliko skupina:

- informacijsko preopterećenje - kompulzivno „surfanje“ internetom ili pretraživanje baze podataka, što dovodi do smanjene produktivnosti rada i manje socijalne interakcije s prijateljima i obitelji

- mrežnu kompulzivnost - kompulzivno igranje internetskih igara, kockanje, trgovinu dionicama ili korištenje internetskim aukcijama, što često dovodi do financijskih i poslovnih problema

- ovisnost o virtualnim vezama - ovisnost o društvenim mrežama, „pričaonicama“ i SMS porukama do točke kada virtualni prijatelji postaju važniji od stvarnog života i odnosa s prijateljima i obitelji

- ovisnost o „virtualnom seksu“ („Cybersex addiction") - kompulzivno korištenje internetskom pornografijom, „pričaonicama“ (chat rooms) za odrasle ili sličnim internetskim stranicama s negativnim utjecajima na intimne odnose u stvarnom životu

- ovisnost o računalu - opsesivno igranje računalnih igara ili opsesivno računalno programiranje ${ }^{6}$. 


\subsection{Prevalencija ovisnosti o internetu}

Procjenjuje se da je $6 \%$ do $11 \%$ korisnika interneta u SAD-u ovisno o internetu ${ }^{14}$.

Provedena istraživanja i kod nas dobila su slične rezultate, primjerice prema istraživanju koje proveo dr. Zoran Šimić 2001. godine na web-stranici www.psihologija.ims.hr putem upitnika OVINET dobiveni su rezultati da $11 \%$ osoba koje su ispunjavale upitnik ima poteškoća zbog prekomjernog korištenja internetom ${ }^{15}$.

lako istraživanja u različitim zemljama i kulturama primjenjuju različite metode i metodologije istraživanja, generalno se može zaključiti da je prevalencija ovisnosti o internetu najniža među adolescentima i kreće se od 4,6 do 4,7 \%, dok raste na 6 do $15 \%$ u općoj populaciji, a najviša je među studentskom populacijom i kreće se od 13 do $18,4 \%{ }^{10}$. Ta se populacija smatra najrizičnijom za stvaranje ovisnosti o internetu ${ }^{16}$.

\subsection{Simptomi ovisnosti o internetu}

Kao što je prethodno rečeno, ovisnost o internetu pokazuje slična obilježja kao i ovisnost o kockanju i psihoaktivnim tvarima: jaku želju za stalnim korištenjem, povišenu toleranciju, psihičku ovisnost, štetno djelovanje na osobu, obitelj i društvo, smanjenu učinkovitost na poslu ili u školi / na fakultetu, a u slučaju prekida korištenja izvorom ovisnosti javljaju se simptomi apstinencijske krize ${ }^{5}$.

Neki od psiholoških znakova i simptoma ovisnosti o internetu:

- gubitak pojma o vremenu provedenom na internetu

- problemi u izvršavanju zadataka kod kuće, na poslu ili u školi / na fakultetu

- izoliranje od obitelji ili prijatelja

- osjećaj krivnje i pronalaženje izgovora o vremenu provedenom na internetu

- osjećaj euforije ili opuštenosti prilikom korištenja internetom

- neraspoloženost, nervoza i ljutiti ispadi kod prekida korištenja izvorom ovisnosti

- gubitak interesa za ostale aktivnosti

- financijski problemi (npr. veliki telefonski računi)

- izostanak intimnosti s partnerom zbog vremena provedenog na internetu, razvodi veza/brakova zbog „internetskih afera“ 6

- razmišljanje o internetu kada osoba nije na njemu, o tome kako će i kada ponovno započeti korištenjem $^{15}$.
Osobe koje su ovisne o internetu sklonije su i problemima mentalnog zdravlja kao što su depresija i anksioznost, psihosomatskim smetnjama, poremećaju hiperaktivnosti i deficita pažnje, neurološkim poremećajima te problemima u ponašanju i drugim ovisnostima ${ }^{14}$.

Prekomjernim korištenjem internetom, osim navedenog, osoba se pokušava nositi s negativnim raspoloženjima i pokušava smanjiti stres, a zamjenjuje ostale aktivnosti i socijalne interakcije vremenom provedenim na internetu iako je svjesna štetnih posljedica takvog ponašanja ${ }^{14}$.

Osim psihičkih poteškoća, ovisnost o internetu izaziva i niz tjelesnih tegoba kao što su sindrom karpalnog kanala (bol i ukočenost u rukama i zglobovima), suhe oči i naprezanje očiju, bol u vratima i leđima, jake glavobolje, poremećaji spavanja, naglašeno debljanje i mršavljenje i $\mathrm{dr}^{6}$

Samo vrijeme provedeno na internetu ne može biti indikator ovisnosti o internetu, s obzirom na to da je kod nekih zanimanja internet osnovni alat za rad, a i za studenta je vjerojatnije da će više vremena provoditi na internetu zbog učenja ${ }^{15}$. No iako vrijeme provedeno na internetu nije direktan pokazatelj ovisnosti o internetu, istraživanja pokazuju da osobe koje su kvalificirane kao internetski ovisnici provode 40 do 80 sati tjedno na internetu, a vrijeme provedeno na internetu može trajati neprekidno i do 20 sati, uzrokujući nedostatak sna i umor, probleme u izvršavanju zadataka kod kuće, na poslu ili u školi / na fakultetu te rizik od raznih tjelesnih tegoba ${ }^{10}$.

Istraživanje Poliklinike za zaštitu djece grada Zagreba iz 2013. godine (,Koliko vremena i uz koje rizike djeca provode na internetu i Facebooku“) pokazalo je da djeca koja imaju manju kontrolu nad korištenjem internetom (primjerice teže im je otići s interneta, češće razmišljaju o internetu kad nisu na njemu, više zanemaruju svoje obveze zbog interneta...) imaju lošiju sliku o sebi, tjeskobnija su, pokazuju više simptoma depresivnosti te su sklonija neprihvatljivom ponašanju. Jedno od desetero djece u navedenom istraživanju smatra da zbog interneta zanemaruje svoje svakodnevne obveze. $\mathrm{Na}$ internet $15 \%$ djece odlazi kad se osjeća loše, a $12 \%$ da bi pobjegli od tuge ili neugodnih osjećaja. Zbog prekomjernog korištenja internetom čak $9 \%$ djece ima osjećaj nedostatka sna, a $10 \%$ ih se osjeća nemirno i razdražljivo kada ne mogu otići na internet. Svako šesto dijete nastoji što brže riješiti domaću zadaću da bi moglo što prije doći na internet, a $26 \%$ djece svoje slobodno vrijeme najčešće provodi na internetu ${ }^{17}$. 


\section{6. Čimbenici rizika razvoja ovisnosti o internetu}

Među čimbenicima rizika svakako je važan situacijski faktor, koji može igrati ulogu u razvoju ovisnosti o internetu. Internet može postati bijeg u virtualni svijet od problema i teških situacija u stvarnom životu ${ }^{10}$.

Također, osobe koje imaju povijest ovisnosti o alkoholu ili drogi mogu u pretjeranom korištenju internetom naći fizički sigurniju alternativu svojoj ovisničkoj sklonosti, smatrajući da je medicinski sigurnije biti ovisan o internetu nego o psihoaktivnim tvarima, izbjegavajući se suočiti s uzrocima ovisničkog ponašanja ${ }^{10}$.

U najvećem su riziku osobe koje pate od više vrsta ovisničkog ponašanja, a internet se tu čini kao zgodan pravno i fizički siguran način za bijeg od nošenja s problemima u stvarnom životu. Osobama koje pate od ovisnosti o seksu ili kockanju internet služi kao novi zaklon za upuštanje u takve aktivnosti ${ }^{10}$. Situacijsko bježanje u pretjerano korištenje internetom ne mora uvijek voditi u ovisnost o internetu, ali ako to postaje kroničan i trajan način nošenja s problemima, može voditi u kompulzivno korištenje, odnosno ovisnost o internetu ${ }^{10}$.

Osobe mogu postati ovisne o internetu zbog raznih problema s kojima moraju živjeti, a u posebnom su riziku od razvoja ovisnosti o internetu anksiozne i depresivne osobe, osobe koje pate od drugih oblika ovisnosti, hiperaktivne osobe, osobe sa smanjenom socijalnom potporom, smanjenom mobilnošću i društvenom potporom te osobe pod stresom ${ }^{6}$. Ako je neki od ovih modaliteta posebno izražen ili je prisutno više njih, osoba je podložnija razvoju ovisnosti o internetu zbog smanjenog kapaciteta suočavanja s problemima ${ }^{10}$.

Stoga je internet nekada samo modalitet u kojem se izražavaju te teškoće te se često ističe da nije tehnologija sama po sebi ta koja izaziva ovisnost ${ }^{15}$. Zato je važno da stručnjak koji radi s osobom ovisnom o internetu utvrdi je li kompulzivno korištenje internetom samo modalitet za izražavanje teškoća u stvarnom životu ${ }^{10}$.

Nužno je i da se buduća istraživanja na području ovisnosti o internetu orijentiraju na povezanost nekih psihijatrijskih bolesti i poremećaja s razvojem ovisnosti o internetu. Longitudinalna istraživanja mogu otkriti kako osobine ličnosti, obiteljska dinamika ili interpersonalne vještine utječu na način na koji se ljudi koriste internetom, a sve je to nužno kako bi se odredili efikasni načini terapijskih pristupa liječenju ove ovisnosti i usporedili s tradicionalnim liječenjima ovisnosti ${ }^{10}$.

\subsection{Liječenje ovisnosti o internetu}

Ovisnost o internetu vjerojatno je jedna od najteže izlječivih ovisnosti, s obzirom na to da se ljudi svakodnevno koriste internetom i jedan je od najvažnijih medija u našem životu te prilikom liječenja ne možemo u potpunosti izbaciti internet iz života korisnika ${ }^{6}$. Tu je i najveća razlika između ovisnosti o internetu i drugih vrsta ovisnosti, gdje se umjesto izbacivanja predmeta ovisnosti korisnika uči konstruktivno služiti internetom.

Međutim, nekad je nužno izbaciti korištenje određenim uslugama na internetu, kao što su „pričaonice“, mrežne igre ili stranice s pornografijom, jer konstruktivno služenje ostalim sadržajima interneta može tu podbaciti zbog inherentnog obilježja interneta gdje stranice sa zabranjenim sadržajima mogu mamiti osobu te se mora pribjeći potpunoj zabrani korištenja internetom sve dok se u postupku liječenja ne uspostavi kontrola i osoba se ne nauči konstruktivno služiti internetom ${ }^{10}$.

Liječenje ovisnosti o internetu razlikovat će se i s obzirom na vrstu ovisnosti o internetu. Primjerice, osoba ovisna o internetskim igrama zahtijevat će drugačiji pristup liječenju od osobe ovisne o pornografskim stranicama, a kao što je već rečeno, ovisnost o internetu može biti samo simptom drugih problema koje osoba ima, dok je internet samo medij kroz koji ih izražava ${ }^{10}$.

Kao i kod svih drugih vrsta ovisnosti, osobe će na početku negirati ili minimalizirati problem prekomjernog korištenja internetom i njegova utjecaja na njihov život, a često su članovi obitelji ili druge bliske osobe te koje ih nagovaraju da potraže pomoć. Kako bi se osobu potaknulo na rješavanje problema, nakon dijagnoze terapeut mora upotrijebiti motivacijske tehnike za pristup liječenju, kako bi osoba uvidjela u kojoj mjeri internet utječe na njezin svakodnevni život i koje posljedice ostavlja te kako bi se motivirala za liječenje kroz partnerski odnos terapeuta i korisnika ${ }^{10}$.

Na početku liječenja važno je i utvrditi ima li osoba povijest ovisničkog ponašanja, jer nekada osobe ovisne o alkoholu i drogama postaju ovisne o internetu, smatrajući tu ovisnost zdravijom alternativom. Osobe koje pate od više vrsta ovisnosti imaju najveći rizik od ponovnog recidiva ${ }^{10}$.

Također, osobe koje su ovisne o internetu mogu patiti od brojnih psihičkih i osobnih problema, a internet vide kao sigurno mjesto na kojem mogu smanjiti napetost, tugu ili stres ${ }^{10}$.

Prekomjerno korištenje internetom može biti i posljedica interpersonalnih problema, kao što je introverti- 
ranost, ili socijalnih problema ${ }^{10}$. Mnogi ovisnici o internetu ne funkcioniraju dobro $u$ odnosima licem u lice te im se komunikacija u virtualnom svijetu čini lakšom i sigurnijom, a loše komunikacijske vještine mogu voditi niskom samopoštovanju i izolaciji, zbog čega terapeut mora utvrditi na koji način osobe komuniciraju u stvarnom životu ${ }^{10}$. Drugi pak mogu imati lošu socijalnu podršku okoline, zbog čega se okreću odnosima u virtualnom svijetu kada se osjećaju usamljeno ili žele s nekime razgovarati ${ }^{10}$.

Sve se te osobe okreću internetu umjesto da se bave problemima $u$ interpersonalnim odnosima, financijskim problemima, bračnim problemima, problemima na poslu ili u školi, smatrajući internet društveno prihvatljivom sigurnom zonom. Zbog svoje ovisnosti o internetu osobe često zanemare ili izgube bitne odnose sa svojim bližnjima u stvarnom životu, a kako bi se postigao oporavak, ti odnosi moraju ponovno biti uspostavljeni, zbog čega može biti nužno i uključivanje tih osoba u tretman kroz obiteljsku ili partnersku terapiju kako bi se osobe upoznale s ovisnošću i angažirale se u procesu oporavka ${ }^{10}$.

Budući da ovisnost o internetu ima dosta sličnosti s drugim tipovima ovisnosti i opsesivno-prisilnog ponašanja, primjenjuju se i slični tipovi i kombinacije liječenja. Uglavnom je riječ o psihoterapijama i farmakološkim intervencijama.

Mnogi autori, kao što su Davis i Young, nude kognitivnobihevioralni model kao najbolji za ovisnost o internetu, naglašavajući kognitivne simptome kao što su opsesivne misli o internetu, smanjena kontrola poriva, nesposobnost prekidanja upotrebe interneta i osjećaj da je internet jedini prijatelj ${ }^{15}$. U navedenom modelu uspješno se može primjenjivati kognitivno-bihevioralna terapija koja počiva na premisi da naše misli određuju naše osjećaje. Prema Kimberly S. Young, pokazala se uspješnom u liječenju ove vrste ovisnosti ${ }^{10}$. Kod kognitivnobihevioralne terapije pokušavaju se postići promjene u mišljenjima i uvjerenjima kod osobe u cilju dugotrajnog mijenjanja misli, ponašanja i emocionalnih odgovora kod pacijenata. Terapeuti moraju pomoći klijentima u rješavanju problema koji se skrivaju iza ovisnosti o internetu, identificirati nove ciljeve i naučiti nova ponašanja i odgovore na probleme ${ }^{10}$.

Također, kao način liječenja ovisnosti o internetu neki autori proučavaju utjecaj farmakološkog liječenja, koje se primjenjuje i kod drugih vrsta ovisnosti, polazeći od pretpostavke da sve ovisnosti uzrokuju promjene u neurotransmiterima, što može biti posebno djelotvoran način liječenja kod pacijenata koji pate i od drugih psihičkih problema uz ovisnost o internetu. Ovaj se način liječenja u nekim studijama pokazao učinkovitim, iako je takvih studija za sada relativno malo i nužna su daljnja istraživanja koja će dati jasniji uvid o utjecaju farmakološkog liječenja na ovisnost o internetu. Jedna od takvih studija provedena je na sveučilištu „Mount Sinai School of Medicine" u New Yorku, gdje su istraživači testirali uporabu antidepresiva escitalopram na 19 kompulzivnih korisnika interneta, a rezultat je bio prosječno smanjenje sati provedenih na internetu sa 36 na 16 sati tjedno ${ }^{10}$.

Kao načini liječenja u literaturi ${ }^{18}$ se navode i već spomenuti motivacijski intervju, realitetna terapija, obiteljska terapija i drugi bihevioralistički terapijski modeli, a vrlo se često sve te tehnike kombiniraju u procesu liječenja.

\section{Ovisnost o internetskim (online) igrama}

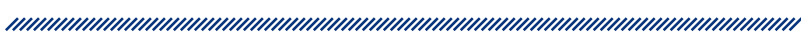

Ovisnost o internetskim igrama postaje sve ozbiljniji problem u svijetu. Prepoznaje se kad razina igranja videoigara dosegne razinu da zbog takvih aktivnosti nastanu ozbiljne poteškoće u funkcioniranju osobe u obitelji, društvu i školi te poteškoće u psihološkom funkcioniranju ${ }^{19}$.

Kao što je spomenuto ranije, u priručniku DSM-V među stanjima za daljnja istraživanja navedena je i „Ovisnost o internetskim igrama“, a prema Američkoj psihijatrijskoj udruzi dodatna bi istraživanja mogla eventualno pokazati da ovisnost o internetskim igrama zaslužuje biti neovisan poremećaj ${ }^{11}$.

Ovisnost o Internetskim igrama oblik je pretjeranog $i$ prolongiranog igranja na Internetu koji rezultira skupinom kognitivnih simptoma i simptoma ponašanja, uključujući progresivni gubitak kontrole nad igranjem, toleranciju i simptome sustezanja, analogno simptomima poremećaja uzimanje psihoaktivne tvari. Kao u poremećajima povezanim s psihoaktivnim tvarima, osobe s ovisnosti o Internet igrama nastavljaju sjediti za kompjuterom i sudjelovati u igrama unatoč zanemarivanju drugih aktivnosti. Oni se obično 8-10 ili više sati dnevno predaju ovoj aktivnosti, a najmanje 30 sati tjedno. Ako ih se spriječi u korištenju 
kompjutera i povratku igri, oni postaju uznemireni $i$ ljuti. Često provode dugo razdoblja bez hrane i spavanja. Uobičajene se obveze, kao što su škola, posao ili obiteljske obveze zanemaruju $u^{11}$.

U priručniku DSM-V predloženo je devet kriterija za dijagnosticiranje ove ovisnosti kao perzistirajuće i ponavljajuće upotrebe interneta radi sudjelovanja u igrama koja dovodi do klinički značajnog oštećenja ili patnje, a da bi se dijagnosticirala ovisnost, mora biti zastupljeno pet ili više kriterija ${ }^{11}$.

\section{Elektroničko nasilje među djecom (cyberbullying)}

\subsection{Definicija elektroničkog nasilja}

Postoje razna tumačenja što je točno nasilje na internetu, ali elementi su koji su više-manje zajednički svim definicijama korištenje tehnologijom (računalom, mobilnim telefonom, tabličnim računalom i drugim elektroničkim uređajima) koje ima za cilj nanijeti štetu, odnosno povrijediti drugu osobu, a uglavnom nije riječ o izoliranom incidentu, već o ponavljajućem ponašanju ${ }^{20}$.

Ova vrsta nasilja služi se elektroničkom poštom, blogovima, SMS i MMS porukama, web-stranicama, društvenim mrežama, telefonima i sl., može biti u obliku tekstualnih ili slikovnih poruka, videozapisa ili poziva, a uključuje višestruko poslane poruke putem interneta ili mobitela, koje imaju za cilj povrijediti, uznemiriti ili na bilo koji drugi način oštetiti dijete, mladu ili odraslu osobu koji se ne mogu zaštititi od takvih postupaka ${ }^{6}$.

Također obuhvaća i poticanje na grupnu mržnju, širenje nasilnih i uvredljivih komentara o vršnjaku, osmišljavanje i stvaranje internetskih stranica koje sadrže priče, crteže, slike i šale na račun vršnjaka, slanje tuđih fotografija te traženje ostalih da ih procjenjuju po određenim karakteristikama, „provaljivanje“ u tuđe adrese e-pošte, seksualno namamljivanje i izlaganje sadržajima neprimjerenima dobi djeteta i mlade osobe, lažno predstavljanje kao druga osoba itd. ${ }^{6}$

Specifičnosti elektroničkog nasilja:

- može biti prisutno 24 sata na dan, svih sedam dana u tjednu
- djeca i mladi izloženi su toj vrsti nasilja kod kuće i na drugim mjestima koja su ranije bila sigurna za njih

- svjedoci nasilja mogu biti mnogobrojni

- anonimnost zlostavljača pojačava osjećaj nesigurnosti kod žrtve

- meta nasilja osim vršnjaka mogu biti i učitelji ${ }^{6}$.

Danas djeca i mladi novi prostor za nasilničko izražavanje i ponašanje pronalaze u virtualnom svijetu, koji im pruža anonimnost, koja nije moguća ni u jednoj drugoj vrsti komunikacije. Upotrebom lažnih imena i različitih lozinki omogućeno je jednostavno skrivanje identiteta te to predstavlja mnogo jednostavniji način ranjavanja drugoga od suočavanja licem u lice $^{6}$.

Upravo zbog toga što se nasilnik skriva iza ekrana, često nije svjestan štete koju nanosi drugoj osobi, a samim time ni posljedica takvog ponašanja ${ }^{1}$.

Stoga je iznimno važno promicati kulturu ophođenja i poštivanja drugog u virtualnom svijetu ${ }^{1}$.

\subsection{Prevalencija elektroničkog nasilja}

Većina je istraživanja pokazala da se postotak djece koja su doživjela nasilje na internetu kreće od $6 \%$ do $30 \%{ }^{20}$. Što se tiče oblika nasilja, prema istraživanju Patchina i Hinduje iz 2010. godine, najviše, $14 \%$ mladih, iskusilo je nasilje u obliku stavljanja uvredljivog i ponižavajućeg sadržaja na internet, zatim $13 \%$ mladih u obliku širenja lažnih glasina, $7 \%$ mladih iskusilo je prijetnje na internetu, a najmanji postotak od $2 \%$ mladih iskusilo je nasilje u obliku stavljanja uvredljivog i ponižavajućeg videosadržaja na internet ${ }^{20}$.

Što se tiče mladih osoba koje su u jednom trenutku primjenjivale nasilje na internetu prema drugoj osobi, taj se postotak prema prethodno navedenom istraživanju kreće oko $16,8 \%$.

Prema istraživanju UNICEF-a („Iskustva i stavovi djece, roditelja i učitelja prema elektroničkim medijima“) iz 2010. godine, $4,90 \%$ učenika doživljava neki oblik vršnjačkog nasilja putem elektroničkih medija, $29 \%$ in to doživi jedan do dva puta mjesečno, a 66,20 \% nikada nije doživjelo elektroničko nasilje. Gotovo $40 \%$ djece to doživi putem Facebooka ili neke druge specijalizirane stranice za druženje, a više od $30 \%$ putem SMS poruka9 .

Što se tiče nasilničkog ponašanja prema drugima, u istraživanju Poliklinike za zaštitu djece grada Zagreba i Hrabrog telefona iz 2008. godine (,Istraživanje o navikama i iskustvima djece i mladih prilikom korištenja Inter- 
neta, mobitela i drugih suvremenih tehnologija") dobiveni su rezultati da je $7 \%$ djece i mladih zloupotrijebilo nečije ime i objavilo tuđe privatne stvari na internetu, $5 \%$ sudionika navelo je da su objavili tuđu sliku ili film s ciljem da se izruguje toj osobi, a $7 \%$ sudionika navelo je da se lažno predstavljalo i govorilo ružne stvari u ime druge osobe ${ }^{8}$.

\subsection{Posljedice elektroničkog nasilja}

Istraživanja pokazuju kako proživljeno iskustvo elektroničkog nasilja, bilo kao žrtva bilo kao nasilnik, može imati značajan utjecaj na emocionalni i psihički razvoj djeteta, iako mnogi elektroničko nasilje ne smatraju pravom vrstom nasilja, s obzirom na to da direktno ne ugrožava fizičku sigurnost žrtve ${ }^{7}$.

Prema istraživanju Patchina i Hinduje, 45 \% žrtava elektroničkog nasilja osjećalo je ljutnju, $28 \%$ frustraciju, a $27 \%$ tugu, dok nešto više od $30 \%$ ispitanika nije imalo negativnu emocionalnu reakciju ${ }^{20}$. Prema raznim istraživanjima, mogu se javiti i druge emocije kao što su strah, sram, bijes i povrijeđenost te čak i simptomi anksioznosti i depresije.

Prema istraživanju UNICEF-a („Iskustva i stavovi djece, roditelja i učitelja prema elektroničkim medijima") iz 2010. godine, gotovo tri četvrtine djece koja nasilje doživljavaju često ili vrlo često osjeća se ljutito (74,67 \%), uznemireno $(71,49 \%)$ i zabrinuto $(70,18 \%)$. Polovica zlostavljane djece ne želi ići u školu $(50,00 \%)$ i osjeća se loše uz glavobolje i trbobolje $(40,67 \%)$, a više od polovice ima poteškoće koncentracije kod kuće i u školi (61,06 \%). Gotovo $40 \%$ zlostavljanje djece istodobno osjeća smetnje spavanja i smanjeni apetit ${ }^{9}$.

Prema istraživanju Patchina i Hinduje iz 2010. godine, identificirana je i veza između elektroničkog nasilja i niskog samopouzdanja studenata, ali nije utvrđeno je li niže samopouzdanje posljedica elektroničkog nasilja ili su osobe s nižim samopouzdanjem češće žrtve nasilja ${ }^{21}$. Ista je veza nađena i kod zlostavljača, što može upućivati na to da osobe nižeg samopouzdanja nalaze svoj prostor u virtualnom nasilju kako bi se osjećale bolje ${ }^{20}$.

Također, u istraživanju Patchina i Hinduje iz 2010. godine pronađena je veza između elektroničkog nasilja i suicidalnih misli i namjera, posebice kod žrtava nasilja. Naravno da elektroničko nasilje samo po sebi ne uzrokuje samoubojstvo, već je riječ o mnogobrojnim povezanim problemima koje te osobe proživljavaju u stvarnom životu. Međutim, kod žrtava elektroničkog nasilja utvrđena je dva puta veća vjerojatnost pokušaja samoubojstva ${ }^{20}$.
Samoubojstvo koje se događa kao posredno ili neposredno iskustvo elektroničkog nasilja Hinduja i Patchin nazvali su „cyberbullicide“21.

Istraživanja su pokazala i da su žrtve elektroničkog nasilja u većem riziku da zapadnu u probleme sa školom i razna druga devijantna ponašanja kao što su konzumiranje alkohola i droge, krađa po dućanima, uništavanje vlasništva, fizičko nasilje i nošenje oružja u školu ${ }^{20}$.

Nažalost, nasilje na internetu često zna prerasti i u nasilje na ulici i u školama22.

\section{Seksualno zlostavljanje djece $\mathrm{i}$ internet}

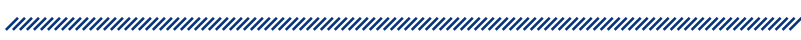

\subsection{Dječja pornografija}

Internet na mnogo načina igra glavnu ulogu u seksualnom zlostavljanju djece, kao lak i anoniman način za konzumaciju i distribuciju dječje pornografije ${ }^{23}$.

Velika potražnja dječje pornografije, nove tehnologije za izradu visokokvalitetnih pornografskih sadržaja, kao i mogućnost njihova pohranjivanja ili izravne distribucije putem interneta na ilegalno svjetsko tržište, omogućuje kriminalnim osobama koje djecu i adolescente koriste za snimanje dječje pornografije brzo i lako stjecanje profita na štetu djece i adolescenata ${ }^{24}$.

Postoje brojni razlozi zbog kojih pedofili konzumiraju pornografiju na internetu, od prikupljanja raznih fotografija djece do seksualno neprimjerenog ponašanja prema djeci² ${ }^{23}$.

Smatra se da postoje tri moguća tipa motivacije prikupljanja dječje pornografije:

- prikupljanje kao dio šireg obrasca seksualnih prijestupa koji mogu uključivati i prijestupe u kontaktu s djecom

- prikupljanje radi poticanja razvoja seksualnog zanimanja za djecu

- gledanje nedoličnih slika djece zbog radoznalosti²3.

Ponašanje pedofila zapravo otkriva njihov adolescentski zastoj razvoja, koji se očituje u ovisničkom prikupljanju dječje pornografije ${ }^{23}$. 
Mnogi pedofili stvaraju zbirke koje se sastoje od tisuća i tisuća slika. Međutim, neke slike nisu nužno eksplicitno pornografske, mnogi pedofili uživaju gledati djecu u prirodnom okruženju, odjevene i bez seksualnih konotacija, dok su erotski sadržaji u umu pedofila, što posebno izaziva zabrinutost, jer to nije moguće zakonski regulirati ${ }^{23}$.

Konzumacija dječje pornografije na internetu omogućuje i kontakt s drugim pedofilima u računalnom svijetu, što pedofilu pruža osjećaj pripadnosti. Kontakt s drugim pedofilima omogućuje upotpunjavanje pornografske zbirke, ali i razmjenu informacija kao što su: kako obraditi dijete, informacije o pronalaženju i odabiru djece, kako izbjeći razotkrivanje, kako zavesti dijete i pripremiti ga za seksualni odnos i $\mathrm{dr}^{23}$

Naposljetku, putem interneta je moguće stupiti u kontakt s ljudima koji djecu nude u seksualne svrhe uz naknadu, u nekim slučajevima razmjenjuju i vlastitu djecu te djecu koju su već „ukrotili“, a koja su prešla poželjnu dob, za mlađu djecu ${ }^{23}$.

Konzumenti dječje pornografije nisu uniformni, potiču ih razni motivi, neki samo gledaju i skidaju pornografski sadržaj, ali se ne upuštaju u seksualno zlostavljanje, neki to čine kao uvod u seksualno zlostavljanje, a neki stvaraju i/ili distribuiraju dječju pornografiju te se mogu i ne moraju upuštati u seksualno zlostavljanje. Također mnogi pedofili seksualno zlostavljaju djecu, a ne konzumiraju dječju pornografiju, tako da je odnos između dječje pornografije i seksualnog zlostavljanja još uvijek dosta nejasan ${ }^{23}$.

Međutim, iako se neki pedofili mogu koristiti dječjom pornografijom kaozamjenom za prijestup, za mnogeje to naputak i poticaj na seksualne prijestupe protiv djece ${ }^{23}$.

Najveći je problem zaštite djece od zloupotrebe na internetu nepostojanje tehnoloških rješenja kojima bi se onemogućio njihov pristup pornografskim sadržajima i privatnim „pričaonicama“ pedofila, koji zloupotrebljavaju njihovo neznanje i naivnost ${ }^{24}$.

\subsection{Vrbovanje djece i mladih - opasnosti „pričaonica“ i drugih komunikacijskih medija na internetu}

Budući da je internet anoniman medij, omogućuje odraslim osobama da se pretvaraju da su djeca, čime djeca misleći da razmjenjuju informacije s drugom djecom mogu pedofilu dati svoje osobne informacije o svojoj dobi, spolu, adresi i školi koju pohađaju, dok neki pedofili mogu biti samo promatrači razgovora i na taj način prikupljati informacije o djetetu ${ }^{25}$.
Dok su prije pedofili na igralištima promatrali djecu i time bili pod određenim rizikom da budu primijećeni, na „virtualnom igralištu“ mogu se skrivati iza anonimnosti interneta ${ }^{25}$. Doduše, ni internet nije u potpunosti anoniman zahvaljujući tehnologiji i zakonskim propisima te je moguće ući u trag računalnima s kojih osoba pristu$\mathrm{pa}^{26}$, no ipak ući u trag počinitelju takvog zločina nije lak ni jednostavan zadatak.

Ako pedofil dobije informacije da je dijete samo, da je računalo u njegovoj sobi i da se njime ne koriste drugi članovi obitelji, „nastojat će zadobiti njegovo povjerenje i uvjeriti ga da moraju vjerovati samo jedan drugome i nikome više “25, ako nešto posumnja, prekida komunikaciju i nestaje, ali kad se uvjeri da nema rizika, tada raznim strategijama pokušava ostvariti trajniju vezu $^{27}$. Nakon što razgovor dođe do ovog stupnja, najčešće pedofil šalje viceve i šale kako bi potaknuo dijete na otvoreniji razgovor te razgovara o djetetovim interesima, hobijima i problemima koje je prethodno saznao vrebajući ${ }^{25}$, stavlja dijete u središte pozornosti i nadoknađuje mu svu onu toplinu, ljubav i nježnost za koju je prikraćeno u svojoj sredini, sve kao dio pripreme za seksualno iskorištavanje ${ }^{27}$. Kako se razgovor nastavlja, pedofil može opisivati seksualne tehnike i poze, tražeći od djeteta da masturbira, a kako bi dijete uvjerio da je to normalno i da to svi rade, može djetetu poslati slike drugih ljudi ili djece uključene u takve aktivnosti, tražeći da to bude njihova tajna ${ }^{25}$. Kako ovakav tip razgovora napreduje i povjerenje raste, pedofil će tražiti dijete da se susretne $\mathrm{s}$ njim ${ }^{25}$.

Danas se sve više zlostavljača okreće mobilnim telefonima, koje djeca, za razliku od računala, imaju stalno sa sobom.

Vrlo se malen broj djece u vezi s time povjerava roditeljima, koji se isto u većini slučajeva osjećaju bespomoćnima i ne znaju kome prijaviti virtualno seksualno zlostavljanje i od koga potražiti pomoć. Također, djecu nitko nije naučio da to mogu prijaviti policiji, administratoru „pričaonice“ ili službi za pritužbe tvrtke koja pruža internetske usluge ${ }^{27}$. Policija je u Hrvatskoj u tu svrhu napravila i aplikaciju „Red Button“ (https://redbutton.mup.hr/) putem koje se može napraviti prijava seksualnog zlostavljanja i iskorištavanja djece.

Prema istraživanju Poliklinike za zaštitu djece grada Zagreba i Hrabrog telefona iz 2008. godine (,Istraživanje o navikama i iskustvima djece i mladih prilikom korištenja Interneta, mobitela i drugih suvremenih tehnologija“), 41 \% djece izjavilo je da su im tijekom druženja i komunikacije na internetu bila postavljana intimna 
pitanja o njima, njihovu tijelu ili pitanja seksualnog karaktera (djevojčice, njih $43 \%$, bile su češće pitane o intimnim detaljima nego dječaci, njih $38 \%$ ). Na pitanje je li netko koga su upoznali na internetu tražio da se slikaju ili snimaju na seksualizirani način $39 \%$ djece navodi da je, ali to nisu učinili, dok $6 \%$ djece navodi da su se slikali i poslali sliku. Čak $31 \%$ djece navodi da im je osoba koju su upoznali putem interneta poslala svoju sliku bez odjeće, a $14 \%$ djece navodi da su otišli na sastanak i upoznavanje s internetskim prijateljem kojeg do tada nisu poznavali uživo. U $14 \%$ slučajeva navode da su kao pratnja išli i roditelji, $49 \%$ navodi da su išli s prijateljima, dok $37 \%$ djece navodi da su otišli na sastanak sami. Ovakav podatak sugerira da je nužno podučavanje djece o mogućim opasnostima pri upoznavanju virtualnih prijatelja koje ne poznaju uživo ${ }^{9}$.

\section{Zaštita djece i mladih na internetu i prevencija ovisnosti}

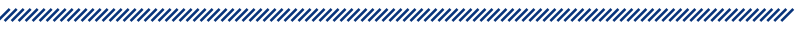

Internet je zajednica koja, kao i svaka druga zajednica, ima svoje dobre i loše članove, svoja sigurna i opasna mjesta, a omjer dobrih i loših ljudi i mjesta ne razlikuje se mnogo ili nimalo od stvarnog svijeta ${ }^{7}$. Uvijek će biti, kao i u stvarnom životu, kriminalnih i domišljatih ljudi koji će naći načina da zloupotrijebe sustav s pomoću novih tehnologija i medija, zato je potrebno sve te rizike procijeniti i naći načine na koje će se njima upravljati?

„Sustav zaštite djece na internetu obuhvaća brojna društvena područja, od obitelji odgojno-obrazovnih ustanova, socijalne zaštite, zdravstvene zaštite te pravosudne zaštite djece.“22

Tu je potrebno i naglasiti da dužnost svih nadležnih tijela, ali i drugih koji saznaju za nasilje putem interneta, proizlazi iz „Protokola o postupanju u slučaju nasilja nad djecom", prema kojem su nasilje dužni prijaviti policiji i Centru za socijalnu skrb, a na kriminalna djela putem interneta uglavnom se mogu primijeniti i razne odredbe Kaznenog zakona ${ }^{22}$.

\subsection{Uloga roditelja, škole i lokalne zajednice u zaštiti djece na internetu $i$ prevenciji ovisnosti}

Kao što smo već rekli, internet može predstavljati opasnost prvenstveno za djecu i mlade, koji često nekon- trolirano pretražuju ovaj medij dolazeći do sadržaja neprimjerenog njihovoj starosti i stupnju razvoja ${ }^{28}$.

Prema istraživanju Poliklinike za zaštitu djece grada Zagreba i Hrabrog telefona iz 2008. godine („Istraživanje o navikama i iskustvima djece i mladih prilikom korištenja Interneta, mobitela i drugih suvremenih tehnologija"), 54 \% djece i mladih izjavilo je da je naišlo na webstranicu koja je sadržavala fotografije golih ljudi ili ljudi u spolnom odnosu, a da to nisu željeli, $24 \%$ djece i mladih navelo je da su primili poruku putem elektroničke pošte koja je oglašavala pornografske web-stranice ili je sadržavala poveznice za te stranice, a da to nisu željeli, a $28 \%$ djece i mladih je otvorilo poruku ili poveznicu koja je sadržavala slike golih ljudi ili osoba u seksualnoj aktivnosti, a da to nisu željeli ${ }^{8}$.

U zaštiti djece na internetu vrlo veliku ulogu igraju roditelji, koji moraju djecu u virtualnom svijetu voditi kao što to čine i u stvarnom svijetu, na način da znaju kakvi rizici na internetu postoje i kako tim rizicima upravljati

Međutim, roditelji se često osjećaju nemoćnima kada njihovo dijete zna više o računalima i internetu od njih samih.

Neki roditelji u strahu od tamnih strana interneta pribjegavaju potpunim zabranama korištenja tim medijem, što u konačnici uzrokuje mnogo više štete za kvalitetan razvoj djeteta i uskraćuje mu dragocjeni izvor znanja i sredstvo potrebno za uspjeh, s obzirom na to da djeca danas moraju biti informatički pismena kako bi uspjela u školi, pohađala fakultet i zaposlila se ${ }^{7}$.

Djecu ne bismo smjeli pretjerano ograničavati u stjecanju potrebnih vještina koje će im omogućiti da funkcioniraju u zajednici, u njima ne treba pobuđivati strah i sumnjičavost, već im treba pružiti dovoljno saznanja primjerenih njihovoj dobi kako bi bila svjesna potencijalnih opasnosti23.

Dok neki roditelji u strahu potpuno zabranjuju djeci ovaj medij, postoje i roditelji koji svojoj djeci daju potpunu slobodu korištenja ovim medijem. Kako roditelji ne bi smjeli djeci potpuno zabranjivati korištenje internetom, tako ne bi smjeli dopustiti djeci ni da njihova želja za privatnošću nadvlada odgovornost roditelja da in nadziru. Roditelji moraju tražiti od djece na uvid stranice koje posjećuju, provoditi s njima vrijeme na internetu i upoznati se s uslugama kojima se djeca koriste ${ }^{25}$.

Prema istraživanju Poliklinike za zaštitu djece grada Zagreba i Hrabrog telefona iz 2008. godine (,Istraživanje o navikama i iskustvima djece i mladih prilikom korištenja Interneta, mobitela i drugih suvremenih tehnologi- 
ja“), 49 \% djece izjavljuje da je bez nadzora i prisutnosti odraslih dok se koristi internetom, dok $46 \%$ njih navodi da su roditelji ponekad prisutni. Tek 2,5\% djece navodi da je jedan od roditelja prisutan uvijek dok su na internetu. Na pitanja o reakcijama roditelja više od polovine sudionika (60\%) izjavljuje da ih roditelji poučavaju o opasnostima povezanima s internetom i načinima zaštite, dok trećina djece (36\%) smatra da njihove roditelje ne zanima što oni rade na internetu

Također, prema istraživanju Poliklinike za zaštitu djece grada Zagreba iz 2013. godine (,Koliko vremena i uz koje rizike djeca provode na internetu i Facebooku“), u većini obitelji nisu jasno postavljena pravila za korištenje internetom i Facebookom, u njih $78 \%{ }^{17}$.

Roditelji ne bi smjeli imajući povjerenja u djecu prepustiti korištenje internetom samo u njihove ruke $\mathrm{i}$ bez nadzora, jer sigurnost na internetu ne ovisi samo o njima već o svim ljudima koji se služe internetom, a za to je potrebno naučiti djecu načinima izbjegavanja opasnosti na internetu isto kako ih učimo pravilima kad su sami kod kuće ili kad prelaze prometnu cestu. Zapravo za loše stvari koje se dešavaju na internetu nije kriv internet, već ljudi koji taj medij zloupotrebljavaju, a roditeljski strah uglavnom proizlazi iz nerazumijevanja i nepoznavanja načina zaštite, ali i oni koji dobro razumiju ovaj medij neće uvijek znati prepoznati rizike kojima su djeca izložena ili/i načine na koje to mogu izbjeći ${ }^{7}$.

Djecu treba podučiti da je stranac ipak stranac. Kako sa strancima ne razgovaraju na ulici ili na igralištu, ista pravila moraju primjenjivati i kod komunikacije na internetu. Važno je upozoriti djecu da davanje i minimalnih informacija može omogućiti stranoj osobi pronalaženje mjesta gdje dijete živi ili ide u školu, a susret s osobom koju je dijete upoznalo preko interneta ne smije se održati bez nazočnosti roditelja ${ }^{25}$.

Koliko će biti koristi ili štete od korištenja računalom osim o vremenu provedenom za računalom ovisi $i$ o tome u koje se svrhe dijete služi računalom i koliko roditelji vode računa o tome. Osim za izvor zabave, roditelji moraju poticati djecu da se koriste računalom $\mathrm{i}$ kao medijem za učenje. Dužinu vremena provedenog za računalom roditelji moraju prvenstveno korigirati iz zdravstvenih razloga te što više poticati kretanje djeteta i provođenje vremena u drugim oblicima igara ${ }^{29}$.

Previše provedenog vremena za računalom može dovesti do različitih problema kao što su povećana agresivnost, pretilost, smanjena fizička aktivnost, nesanica, neuspjeh u školi, smanjenje komunikacije u obitelji te smanjena pažnju i interes ${ }^{29}$.
Stoga Živković ${ }^{29}$ nudi neke savjete za roditelje kako bi provođenje vremena za računalom imalo što manje štetnih utjecaja na djecu i mlade, kao što je postavljanje jasnih pravila za uporabu računala, upoznavanje sa sadržajima kojima se dijete koristi na internetu, uključivanje u igru s djetetom na računalu, razgovaranje s djetetom o iskustvima na internetu, podučavanje o pravilima ponašanja na internetu, instaliranje zaštitnih programa i dr.

Posebno, djecu i mlade treba upozoriti i da je na internetu potrebno zaštiti svoje osobne podatke, a u tu je svrhu udruga „Suradnici u učenju“ uz financijsku potporu Ministarstva uprave izradila tri igre putem kojih djeca mogu prolazeći kroz problemske situacije na internetu učiti o važnosti čuvanja i zaštite osobnih podataka, sigurnosti na društvenim mrežama i sigurnom komuniciranju elektroničkom poštom. Igre su dostupne na internetskim stranicama http://bit.ly/igra1, http:// bit.ly/igra2 i http://bit.ly/igra3.

Također, uz financijsku potporu Ministarstva gospodarstva, Centar za edukaciju i informiranje potrošača i Hrvatska udruga za zaštitu potrošača izradili su igru „Vito u svijetu interneta" putem koje djeca i mladi mogu saznati osnovne informacije o zaštiti na internetu, a dostupna je na internetskoj stranici http://www.tvornica. biz/Vito/Vito05.swf.

Djeci i mladima potrebno je i naglasiti da još uvijek ne postoji način da se ukloni sadržaj koji je netko stavio na internet, što može dovesti do neugodnih situacija s obzirom na to da stvari i događaji koji su jednom objavljeni ostaju trajno te su vidljivi svima, zatim da ne odgovaraju na sumnjive poruke e-pošte, a ako pošiljatelj e-pošte nije poznat, najbolje je potražiti savjet roditelja, kao i ne prihvaćati zahtjeve za prijateljstvo na društvenim mrežama od osoba koje ne poznaju ili s kojima nemaju zajedničkih prijatelja te da se objavom stvari poput fotografija, videosnimaka i sl. na društvenim mrežama gubi kontrola i privatnost nad time, a svako maltretiranje na društvenim mrežama potrebno je prijaviti kako bi zaštitili sebe i druge osobe ${ }^{30}$.

Djeca i mladi ne bi trebali niti prihvaćati besplatan dar u zamjenu za adresu ili neke druge informacije bez dozvole roditelja, ne slati fotografije ili opis sebe ili članova obitelji, ne nastavljati razgovor zbog kojega se osjećaju nelagodno ili koji postaje previše osoban i nikako ne organizirati susrete s nekim koga su upoznali preko interneta, osim u slučaju pristanka roditelja na takav susret, koji tada mora biti na javnom mjestu i u pratnji roditelja ${ }^{24}$.

Da bi zaštitili djecu, roditelji, ali i učitelji, moraju ih dobro poznavati i uspostaviti s njima topao i otvoren od- 
nos u kojem će djeca biti spremna slobodno komunicirati čak i o najosjetljivijim stvarima te moći slobodno govoriti o svojim zabrinutostima i sumnjama ${ }^{23}$.

Roditelji koji nemaju dovoljna znanja o novim tehnologijama trebali bi se upoznati s njima kako bi mogli nadzirati djetetov pristup internetu, a mogu zamoliti i dijete da ih pouči ako zna više od njih te se na taj način dodatno zbližiti i tako nadzirati što dijete radi na internetu ${ }^{23}$. Na internetu postoji mnogo stranica koje pružaju korisne informacije kako razgovarati s djecom o opasnostima interneta i što roditelj može poduzeti kako bi zaštitio svoje dijete.

Kao što je rečeno, važno je da roditelji ne pretjeraju u ograničavanju upotrebe interneta kao pozitivnog medija koji nudi razne prednosti, no treba nadzirati korištenje i primijetiti znakove koji ukazuju na neprimjerenu i pretjeranu upotrebu ${ }^{23}$, jer prema istraživanjima najveći broj iskorištavanja i izlaganja djece neprimjerenim sadržajima dogodio se kad su djeca bila na internetu bez nadzora odraslih ${ }^{24}$.

Uloga je škole u zaštiti djece na internetu također velika. Učitelji provode s djecom više vremena nego druge odrasle osobe, nekada više i od roditelja, a to im pruža jedinstvenu mogućnost da upoznaju djecu s opasnostima na internetu i načinima samozaštite, kao i da prate promjene u njihovu ponašanju $u^{23}$.

UNICEF-ovo istraživanje pokazalo je da su učitelji vičniji korištenju internetom od roditelja, što osnažuje mogućnost prevencije nasilja i rizičnih ponašanja u virtualnom svijetu putem škole, jer učitelji koristeći se više ovim medijem mogu bolje i utemeljenije raspravljati s učenicima o njihovim iskustvima, doživljajima i kretanjima u tom svijetu te im mogu biti bolji vodiči. Jednako tako, istraživanje je pokazalo da učitelji mnogo izraženije od roditelja percipiraju opasnosti interneta za djecu, što znači da na roditeljskim sastancima i radionicama mogu bolje uputiti roditelje na ovu temu9.

Škola može napraviti i prvi korak u edukaciji djece te organizirati razna predavanja i edukacije, slično edukacijama o sigurnosti u prometu. Školski programi mogu obuhvatiti osnovne poruke o sigurnosti na internetu, kao i potencijalnim opasnim situacijama, praćeni savjetima o tome kako ih izbjeći i što napraviti kada se dogode ${ }^{23}$. Isto se tako i policija može uključiti u edukacije o sigurnosti na internetu, jednako kao i u slučaju edukacije djece o sigurnosti u prometu ili opasnostima od droga i alkohola ${ }^{23}$.

Zato je važno da su učitelji, kao i druge organizacije u zajednici, primjereno educirani kako bi mogli kompetentno prenositi znanje i raspravljati o tim pitanjima.
Zaštita djece na internetu i prevencija ovisnosti zahtijeva i suradnju cijele lokalne zajednice i društva, ne samo roditelja, škole, djelatnika policije i službi za zaštitu djece, kako bi se osigurala primjerena zaštita, posebno od seksualnog zlostavljanja putem interneta i nasilja na internetu ${ }^{23}$.

Edukacijske kampanje, i to ne samo namijenjene djeci, stručnjacima i roditeljima već svim osobama, jedini su način osiguravanja primjerene zaštite i prevencijskog načina razmišljanja ${ }^{23}$, a u kreiranje edukacijskih kampanja poželjno je da budu uključena i sama djeca ${ }^{31}$.

Primjer dobre prakse u Hrvatskoj svakako je projekt „Sigurnost djece na internetu“ koji je financirala Europska unija, a nositelji su projekta pet osnovnih škola u Hrvatskoj. Svrha je projekta podizanje svjesnosti o opasnostima na internetu i razvoj novoga školskog kurikula o sigurnosti djece na internetu. Projekt je uspješno završen te se kasnije proširio i na druge osnovne škole, a sve o projektu može se pronaći na internetskoj stranici http:// www.petzanet.hr.

\subsection{Uloga medija u zaštiti djece na internetu i prevenciji ovisnosti}

Na naša viđenja i opažanja svijeta značajno utječu medijske konstrukcije realnosti, zbog čega su danas mediji jedno od najmoćnijih sredstava promjene $u$ društvu ${ }^{32}$.

Zato bi veliku ulogu u zaštiti djece na internetu trebali imati i mediji, podupirući edukaciju javnosti o tim pitanjima i šireći odgovarajuće informacije, a izbjegavajući senzacionalistički pristup izvještavanja ${ }^{23}$. Mediji imaju snažan utjecaj na oblikovanje i održavanje stavova i vjerovanja, no i mogućnost iskrivljavanja činjenica i manipuliranja javnim mnijenjem ${ }^{23}$.

Stoga je nužan pedagoški odnos prema medijima, odnosno medijsko obrazovanje, koje bi također trebalo naći svoje jasno mjesto u školskom kurikulu, s obzirom na to da se kod nas odgoj o medijima smatra dijelom različitih predmeta i pri tome u velikoj mjeri ovisi o inicijativi pojedinih nastavnika ${ }^{32}$.

Tu se ističe važnost medijske kompetencije, koja uz medijsku pismenost vodi općem medijskom odgoju, a što znači da nije samo dovoljno znati kako se služiti računalom i internetom, već znati promatrati medije na kritičan način s osjećajem odgovornosti ${ }^{32}$.

Medijske kompetencije trebale bi se integrirati u školski kurikul ponajprije radi sprječavanja medijske manipulacije i medijskog nasilja ${ }^{33}$. 


\section{Zaključak}

Tehnološki napredak otvorio je velike mogućnosti dostupnosti informacija, ali „odgojnih je sadržaja sve manje, a manipulativnih sve više" ${ }^{\text {"33. }}$.

Mediji danas, posebice elektronički mediji, igraju veliku ulogu u životima djece i mladih, kojima predstavljaju put do edukativnih, informativnih i zabavnih sadržaja, prenoseći poruke o životnim vrijednostima i aktualnim trendovima ${ }^{34}$. Danas su jedan od glavnih čimbenika socijalizacije mladog naraštaja, a osim što utječu na zauzimanje stavova prema relevantni društvenim problemima, utječu i na kvalitetu komunikacije, a sve više socijalizacijski istiskuju školu, obitelj i crkvu ${ }^{33}$.

Djeca danas provode više vremena pred raznim elektroničkim uređajima gledajući televiziju, igrajući računalne igrice, „surfajući“ internetom, dopisujući se preko društvenih mreža i raznih drugih internetskih „pričaonica" nego u školi ili igri s vršnjacima u prirodi. Prema nekim istraživanjima vrijeme provedeno pred ekranom izjednačilo se s vremenom provedenim u školi33, a prema nekima je ono i dulje od vremena koje djeca provedu u školskim klupama ${ }^{35}$.

Internet uz mnoge pozitivne učinke nosi i određenu količinu rizičnih i štetnih sadržaja za zdrav psihosocijalni razvoj djece i mladih, međutim riječ je o još dosta neistraženoj problematici koja zahtijeva dodatni i kontinuirani istraživački uvid ${ }^{34}$.

Također, pretjerana upotreba ovog medija može dovesti i do socijalne izolacije, što je dobra podloga za stvaranje ovisnosti.

Osim konstantnog rada na napretku tehnologije i infrastrukture i efikasnosti filtara softvera, važno je raditi na stalnom povećanju svijesti o ovoj problematici, uz uključivanje djece i mladih kao aktivnih sudionika ${ }^{31}$.

Budući da je obitelj glavni zaštitni čimbenik u zdravom odrastanju i ima iznimno važnu ulogu u formiranju načina provođenja slobodnog vremena u kojem se djeca i mladi koriste elektroničkim medijima, nameće se kao nužnost postojanja edukacijskih radionica za roditelje i njihovu djecu o mogućim rizicima elektroničkih i drugih medija za psihosocijalni razvoj djece i mladih te o strategijama prevencije njihova štetnog djelovanja ${ }^{34}$. Djeci nikako ne treba zabranjivati ovaj medij. Jedina je zaštita edukacija i odgoj djece za samozaštitu, uz dobre uzore i nadzor ${ }^{27}$.

Također, kao bitni resursi prevencije tu su i škola i lokalna zajednica te je stoga potrebno izgraditi dobar komu- nikacijski kanal na relaciji djeca i mladi - obitelj - škola - lokalna zajednica, sustavno djelujući na prevenciji i zaštiti djece od mogućega štetnog djelovanja elektroničkih medija ${ }^{34}$, a kad je riječ o dječjoj pornografiji, nužne su i usklađene akcije na međunarodnom planu.

Svoje mjesto u prevenciji i liječenju ovisnosti o internetu svakako imaju i socijalni radnici, koji zbog prirode svojega posla mogu detektirati probleme koje uzrokuje prekomjerno korištenje internetom, sudjelovati u prevenciji putem edukacija i savjetovanja te u suradnji s drugim stručnjacima sudjelovati u kriznim intervencijama i grupama za podršku u svrhu liječenja ovisnosti o internetu. Socijalni su radnici zaposleni u centrima za socijalnu skrb i drugim nadležnim tijelima i glavna karika u poduzimanju odgovarajućih mjera obiteljskopravne zaštite, kad je riječ o elektroničkom nasilju, kako u odnosu na djecu počinitelje tako i u odnosu na djecu žrtve elektroničkog nasilja ${ }^{22}$. 


\section{Literatura}

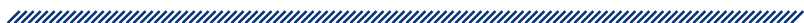

1. Mandarić V. Novi mediji i rizično ponašanje djece i mladih. Bogoslovska smotra. 2012;82(1):131 -149.

2. Car S. Online komunikacija i socijalni odnosi učenika. Pedagogijska istraživanja. 2010;7(2):281-290.

3. Ružić N. Zaštita djece na Internetu. Nova prisutnost. 2011;9(1):155-170.

4. Bilić V, Gjukić D, Kirinić G. Mogući učinci igranja računalnih igrica i videoigara na djecu i adolescente. Napredak. 2010;151(2):195-213.

5. Stanić I. Ovisnost o internetu, cyber kockanju - kako ih sprječavati. Napredak. 2010;151(2):214-235.

6. International Police Association (IPA), Hrvatska sekcija. Internet, ovisnost i mladi. Zagreb: IV Nakladništvo; 2015.

7. Aftab P. Kako prepoznati opasnosti Interneta, vodič za škole i roditelje. Zagreb: Neretva; 2003.

8. Istraživanje o korištenju interneta, mobitela i drugih tehnologija. Poliklinika za zaštitu djece grada Zagreba [internet]. Dostupno na: http://www.poliklinika-djeca.hr/ istrazivanja/istrazivanje-o-koristenju-interneta-mobitela-i-drugih-tehnologija (pristupljeno 25.07.2015.)

9. Istraživanje o iskustvima i stavovima djece, roditelja i učitelja prema elektroničkim medijima. UNICEF [internet]. Dostupno na: http://www.unicef.hr/upload/ file/353/176706/FILENAME/Izvjestaj_-_Iskustva_i_stavovi_djece_roditelja_i_ucitelja_prema_elektronickim_ medijima.pdf (pristupljeno 25.07.2015.)

10. Young KS, Nabuco de Abreu C. Internet addiction, A Handbook and Guide to Evaluation and Treatment. New Jersey: John Wiley \& Sons, Inc.; 2011.

11. Američka psihijatrijska udruga. Dijagnostički i statistički priručnik za duševne poremećaje, peto izdanje. Jastrebarsko: Naklada Slap; 2014.

12. Young KS. Internet addiction: The Emergence of a new clinical disorder. CyberPsychology and Behavior. 1996;3(1):237-244.

13. Christakis AD. Internet addiction: a 21st century epidemic? BMC Medicine. 2010;8(61):1-3.

14. Li W, O'Brien JE, Snyder SM, Howard MO. Characteristics of Internet Addiction/ Pathological Internet Use in U.S. University Students: A Qualitative-Method Investigation. PLOS ONE. 2015;10(2):e0117372

15. Šimić Z, Kolesarić V. Postoji li ovisnost o internetu? Suvremena psihologija. 2002;5(2):227-251.

16. Yeap ALJ, Ramayah T, Kurnia S, Halim HA, Ahmad NH. The Assesment of Internet addiction among university students: some findings from a focus group study. Tehnički vjesnik. 2015;22(1):105-111.

17. Istraživanje koliko vremena i uz koje rizike djeca provode na internetu i facebooku. Poliklinika za zaštitu djece grada Zagreba [internet]. Dostupno na: http://www.poliklinikadjeca.hr/aktualno/rijec-ravnateljice/nase-istrazivanje-ko- liko-vremena-i-uz-koje-rizike-djeca-provode-na-internetu-i-facebooku (pristupljeno 25.07.2015.)

18. Cash H, Rae DC, Steel HA, Winkler A. Internet Addiction: A Brief Summary of Research and Practice. Current Psychiatry Reviews. 2012;8(4):292-298.

19. Bilić V, Ljubin Golub T. Patološko igranje videoigara: uloga spola, samopoštovanja i edukacijske sredine. Hrvatska revija za rehabilitacijska istraživanja. 2011;47(2):1-13.

20. Patchin JW, Hinduja S. Cyberbullying prevention and response: expert perspectives. New York and London: Routledge; 2012.

21. Hinduja S, Patchin JW. Bullying, cyberbullying, and suicide. Archives of Suicide Research. 2010;14(3):206-221.

22. Pezo A. Uloga odraslih u zaštiti djece na Internetu. U: Flego M, ur. Pravobranitelj za djecu. Dječja prava i slobodno vrijeme, Zbornik priopćenja s tribina pravobraniteljice za djecu. Zagreb: Pravobranitelj za djecu; 2010.

23. Sanderson C. Zavođenje djeteta: Kako zaštititi djecu od seksualnog zlostavljanja- smjernice za roditelje i učitelje. Zagreb: V.B.Z; 2005.

24. Stanić I. Pornografija na internet i zaštita djece. Dijete $i$ društvo. 2007;9(1):125-139.

25. Buljan Flander G, Karlović A, Ćosić I. Izloženost djece zlostavljanju putem interneta. Medix. 2004;10(54/55):159-161.

26. Maleš L. Putovima interneta - osnove za odrasle početnike. U: Flego M, ur. Pravobranitelj za djecu. Dječja prava i slobodno vrijeme, Zbornik priopćenja s tribina pravobraniteljice za djecu. Zagreb: Pravobranitelj za djecu; 2010.

27. Stanić I. Pedofilija na internetu - zločin prema djeci. Školski vjesnik. 2007;56(4):573-588.

28. Jeriček H. Internet i ovisnost o internetu u Sloveniji. Medijska istraživanja. 2002;8(2):85-101.

29. Živković Ž. Dijete, računalo i Internet. Đakovo: Tempo, 2006.

30. Forner H, Halilčević S. Ivašković T, Janjušević $A$, Janjušević D, Kanjir S, Katanić M, Martinovsky S, Poslon HI, Špuren F. Sigurno korištenje interneta i Facebooka. Zagreb: Udruga za samozastupanje; 2014.

31. Bilić V, Buljan Flander G, Hrpka H. Nasilje nad djecom i među djecom. Jastrebarsko: Naklada Slap; 2012.

32. Labaš D. Djeca u svijetu Interneta: zatočenici virtualnog svijeta. U: Ciboci L, Kanižaj I, Labaš D, ur. Djeca medija - Od marginalizacije do senzacije. Zagreb: Matica Hrvatska; 2011.

33. Miliša Z, Tolić M, Vertovšek N. Mediji i mladi. Prevencija ovisnosti o medijskoj manipulaciji. Zagreb: Sveučilišna knjižara; 2009.

34. Berc G, Buljevac M. Slobodno vrijeme i mladi-preventivni aspekti. Dijete i društvo. 2007;9(1):25-48.

35. Bilić V. Povezanost medijskog nasilja s agresivnim ponašanjem prema vršnjacima. Odgojne znanosti. 2010;12(2):263281. 


\section{TRAPS OF THE VIRTUAL WORLD: THE PROTECTION OF CHILDREN AND YOUNG PEOPLE ON THE INTERNET AND PREVENTION OF ADDICTION}

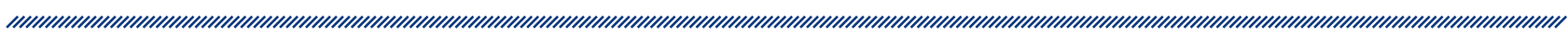

1 Petra Robotić

1 University of Zagreb, Department of Social Work, Faculty of Law

\section{Abstract

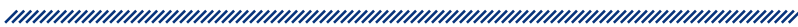

The development of the electronic media, their interactivity and greater opportunities to communicate alongside many advantages and interesting ways of learning, presents a very big risk for everyone, mostly children and young people. Children and young people today have much different lifestyles than their parents and they know a lot more about the electronic media which makes the parental role even more complex. The media today, with emphasis on the growing importance and presence of the electronic media in the lives of children and young people, become educators of the new generations, since children today spend more time in the company of different media than at school.

Therefore, the overuse of the media may lead children and young people into social isolation, which is a good basis for the development of addiction.

There is still no official diagnosis for Internet addiction in the Diagnostic and Statistical Manual of Mental Disorders, Fifth edition (hereinafter referred to as DSM-V) or International Statistical Classification of Diseases and Related Health Problems, Tenth edition (hereinafter referred to as ICD-10) but previous research indicated that some online users were becoming addicted to the Internet in the same way that others become addicted to drugs or alcohol, and the consequences are manifested in social, work and family life of a person.

Furthermore, there are many dangers on the Internet, and the protection of children and young people requires good cooperation and communication between children, parents, schools, local community and society as a whole, systematically acting at all levels of prevention and protection of children from possible harmful effects of the electronic media.

Keywords: Internet, Internet addiction, electronic media, protection of children, prevention. 